\title{
Reflection of foreign language students in higher education: metatextual level
}

\author{
Irina Bobykina $^{1}$, Tatiana Mikheeva ${ }^{2}$, and Irina Prikhoda $^{1^{*}}$ \\ ${ }^{1}$ Chelyabinsk State University, Brat'ev Kashirinyh st., 129, Chelyabinsk, 454001, Russia \\ ${ }^{2}$ Don State Technical University, Gagarin sq., 1, Rostov-on-Don, 344000, Russia
}

\begin{abstract}
The article deals with the concept of linguistic reflection in the field of foreign language education and its verbalization on metatextual level. The ability for linguistic reflection is an indicator of a developed linguistic personality. The purpose of this research is to study the reflection of foreign language students in higher school. Definitions of the key concepts for this work are given: linguistic personality and linguistic reflection. Linguistic reflection can be verbalized through metatextual inclusions: metatextual elements and metatext. The definitions of these concepts, a brief typology and characteristics are given. The material for the study was the texts of foreign language messages (oral, written) of Chelyabinsk State University students. Metatextual inclusions that students use in their foreign language statements are analyzed and classified. The importance of using metatextual inclusions for the statement as a whole is considered. The importance of the ability for linguistic reflection is emphasized not only for the development of a student's linguistic personality, but also for the full functioning of the educational foreign language activity itself. Conclusions are made about the relationship between the ability for linguistic reflection and the common reference level. Students who are capable of reflecting on their linguistic behavior demonstrate a higher level of proficiency in a foreign language.
\end{abstract}

\section{Introduction}

The globalization of the educational space has opened up a lot of opportunities for selfstudy, self-development and self-realization of students. Today it is difficult to imagine an educated, successful person who does not speak a foreign language. Qualitative changes in international relations have made a foreign language a working tool in the practical and intellectual spheres of human activity. A foreign language has ceased to be only the goal of learning. In modern realities, it is a means and one of the factors of social, economic, technical, scientific, cultural development of the world community. A foreign language is now becoming a tool for solving business problems and achieving personal and professional goals. Foreign language education in higher school has a strategically important task - the sustainable continuous development of a person who has needs and the ability to use language in the process of generating and understanding foreign language

* Corresponding author: prihoda-irina@mail.ru 
speech in his educational and professional activities. One of the factors in the development of a linguistic personality is the ability to reflect.

\section{Problem statement}

The expectations of society are related to the fact that modern education, including foreign language education, functioning within the framework of a personality-oriented paradigm, is aimed at shaping the personality of a student capable of further continuous selfdevelopment and self-realization [1]. Achieving this goal is not possible without an important factor - the ability for personal reflection, including linguistic one. Linguistic reflection is understood as the awareness and comprehension of one's own linguistic behavior, the subsequent verbalization of these processes by means of a foreign language. Accordingly, regarding the goals of modern foreign language education, one should talk about the development of the student's ability to reflect on his own linguistic behavior.

\section{Research questions}

Research questions are:

1. To consider the concept of reflection at the linguistic level as a factor in the development of a linguistic personality.

2. To investigate and generalize the means of verbalization of linguistic reflection in the speech of foreign language students at a university.

3. To find out the relationship between the ability of students to reflect and the level of proficiency in the foreign language being studied.

\section{Purpose of the study}

The purpose of this study is to analyze the reflection of the linguistic and discursive behavior of foreign language students in the process of developing the ability to oral and written foreign language communication.

\section{$5 \quad$ Research methods}

The main research methods: analysis of scientific literature, pedagogical experience and products of educational activity, contextual analysis, generalization of metatextual elements as means of implementing linguistic reflection in students' speech, pedagogical observation, testing.

\section{Findings}

One of the tasks of foreign language education in higher school is the continuous development of the language personality. The problem of the linguistic personality is at the origin of the science of language [2]. This concept is studied by representatives of different sciences: linguodidactics, psycholinguistics, cognitive linguistics, etc. (E.G.Belyaevskaya, Yu.N. Karaulov, G.I.Bogin, V.P. Litvinov, A.A. Zalevskaya, etc.) [3]. The concept of a linguistic personality was introduced into wide scientific use by Yu.N. Karaulov [4]. By a linguistic personality, he understands the totality of a person's abilities and characteristics that allow him to create and perceive speech works (oral and written). The general construction of a linguistic personality is considered as a multilevel education, taking into 
account the process of its development. Yu.N. Karaulov [4] identifies three levels of linguistic personality: 1. Verbal-semantic (language proficiency); 2. Cognitive (concepts and ideas that reflect the personal value system); 3. Pragmatic (goals, motives, attitudes) [5, $6]$.

The linguistic personality is expressed through speech activity and is reconstructed through the analysis of linguistic data, i.e. speech of a particular individual (Fig.1). Since a person is an individual and a representative of a collective at the same time, a linguistic person also uses language as an instrument of individual and social cognition of reality in the process of speech production.

A linguistic personality deals with language not only in its communicative function, but also in its meaning-forming and cognizing functions [7].

In this work, a linguistic personality is understood as a person with the ability to diverse (educational, cognitive, scientific, methodological, communicative, personality-oriented, professional) activities using a foreign language for the production and perception of oral and written speech works.

One of the factors in the development of a linguistic personality is the ability to reflect [8].

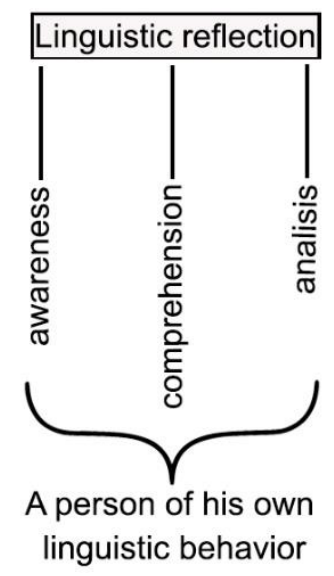

Fig. 1. Understanding of linguistic reflection.

The concept of "reflection" (from Lat. Reflexio - turning back) means the ability of a person to be aware and cognizant of any of his own activities [9].

In a broad practical sense, reflection is seen as a person's ability to self-analyze, comprehend and rethink his relationship with the outside world and is a necessary component of a developed intelligence [10].

The Large Psychological Dictionary defines reflection as a thought process aimed at analysis, understanding, awareness of oneself: one's own actions, behavior, speech, experience, feelings, states, abilities, character, one's tasks, purpose, etc.

Awareness, comprehension and analysis by a person of his own linguistic behavior is understood as linguistic reflection. The concept of linguistic reflection is included in the field of interests of linguistics and appeared in scientific sphere relatively recently. Linguistic reflection can be defined more broadly - as an understanding of the linguistic life of society, linguistic facts, the expression of a certain attitude towards language and everything associated with its usage [11].

Linguistic reflection is a mental process [12], actualized by the means of language, and inextricably linked with the concept of metatext. In linguistics, the META component 
means the most important property of language - the ability to describe oneself, reflexivity, which is the basis of the concept of metatext.

Traditionally, it is believed that the beginning of the metatext study in linguistics was laid in the works of A. Vezhbitska. The researcher considers any text as a two-text: the text itself and the part that comments on it. A similar relationship can arise with one's own utterance, when the speaker abstracts from his words, shares his authorship. Thus, there is a metatext - text within a text.

According to A. Vezhbitska, metatext is words and expressions that have a specific text as a referent and indicate the topic of the statement and the connection between fragments of the text, as well as reveal the speaker's detachment from his words and explicitly or implicitly mention the speech process itself [13].

Thus, metatext (metatextual inclusions) is a verbalization of linguistic reflection.

Consider the linguistic reflection of foreign language students at the metatextual level.

There are two types of metatextual inclusions: metatextual elements and the metatext itself $[14,15]$.

Metatextual elements are words and expressions that have a specific utterance (text) as a referent and perform a metatextual function, in which the utterance / text itself, its structure, principles of construction, coherence, possibilities of perception by the listener or reader become the subject of attention.

Students use the following metatextual elements in their statements:

- with an explicit or implicit verb "to speak": Now I'm going to tell about; I start to talk about ..; I'm asking .., I'm answering ...; In this part I'll talk about ..; Then I'll move on to .., In conclusion I'll say ...; Before I've been talking about ...; This refers to.., Speaking of..; otherwise speaking; Put it in a nutshell..;

The student duplicates information - the listeners understand that he will now speak / answer / continue. In this case, the metatextual inclusion does not carry any new information, it is focused exclusively on the existing utterance.

- Words / expressions, showing the separation of the speaker from his words: It seems as if .. ; So-called, supposed to be ..., as if .., reportedly ..;

Thus, the student, as if describing his own statement from the outside, emphasizes that he is not the primary source of this information, he only transmits it, correctly placing the points of responsibility.

- Elements that indicate the topic of the statement: About this .., of that .., concerning .., as regards .., as far as .. ;

The student focuses the listener's attention on a specific topic at some point in his statement.

- Elements indicating a specific sequence of statements: Firstly, to start with, first off, secondly, in the next place, primarily, afterwards, subsequently, then and there, finally, at last;

Thus, the student, as an author, leads the listener along the event line of his own utterance, which is often evidently traced even without the given commenting metaelements.

- Elements expressing doubt / confidence of the speaker: probably, maybe, I believe .., I'sure .., surely, definitely, potentially, doubtless, very likely, possibly, problematically, uncertainly, doubtfully, It's doubtful, impossibly;

The student demonstrates the modality of the situation, emphasizes his own attitude to the information presented.

- Items that point to major or minor information: above all, the most important thing is .., specifically, most notable, big-ticket item; 
The student focuses the listener's attention on the point of the statement that seems to him at the moment top- priority. At the same time, it is quite possible that the listener himself can understand this from the informational content of the statement.

- Items indicating information already said: As I already announced (said) .., As previously stated ..;

- Elements indirectly referring to subsequent information: And then the unexpected happened..., I couldn't imagine what would happen next;

In the last two examples, the student directs the listener's attention with his metacomments, helps him navigate the structure of the statement and follow the logic of the message.

- Elements that perform a metalinguistic function, in which language simultaneously becomes both an object and a means of research: I don't know how to say it; It's so difficult to say it in English; Sorry for my English; It's difficult for me to pronounce it.

Students often use these metaelements - comments to explain the difficulties encountered in choosing or translating certain units in a foreign language.

Table 1. Metacommentaries of students in a foreign language

\begin{tabular}{|c|c|c|c|}
\hline Group & $\begin{array}{c}\text { Content of } \\
\text { metacommentary }\end{array}$ & Type of information & Student activity \\
\hline $\begin{array}{c}\text { The first } \\
\text { group }\end{array}$ & $\begin{array}{c}\text { The meaning of the } \\
\text { statement }\end{array}$ & $\begin{array}{c}\text { - clarification of the } \\
\text { meaning; } \\
\text { - assessment; } \\
\text { - additional information }\end{array}$ & $\begin{array}{c}\text { Describe a speech } \\
\text { situation }\end{array}$ \\
\hline $\begin{array}{c}\text { The second } \\
\text { group }\end{array}$ & $\begin{array}{c}\text { The process of } \\
\text { creating a statement }\end{array}$ & $\begin{array}{c}\text { - report; } \\
\text { - presentation }\end{array}$ & $\begin{array}{c}\text { Reveal the speaker's } \\
\text { intent }\end{array}$ \\
\hline $\begin{array}{c}\text { The third } \\
\text { group }\end{array}$ & $\begin{array}{c}\text { The reflection of the } \\
\text { student's personality }\end{array}$ & $\begin{array}{c}\text { - information about the } \\
\text { student; } \\
\text { - attitude to the statement; } \\
\text { - attitude to the situation }\end{array}$ & $\begin{array}{c}\text { Demonstrate the } \\
\text { speaker's attitude to } \\
\text { speech }\end{array}$ \\
\hline
\end{tabular}

Metatext is always oriented towards its own pretext. A metatext is understood as any commentary that clarifies the meaning, evaluates, serves the appearance and deployment of certain information, facilitates the listener's perception and understanding of specific speech situations within the framework of his own pretext, that is, an utterance [16-18].

Based on pedagogical observation and analysis of the products of educational activities of non-linguistic university students, three groups of meta-comments can be distinguished, which students use in their statements in foreign language classes.

The first group - comments aimed at the content of the statement: clarification of the meaning, assessment, additional information.

"Stress is the body's response to any changes that change the previous order and require a certain adjustment. The body reacts to these changes with physical, mental, and emotional responses. Eustress (positive, good stress) can actually be beneficial to you ..." (from an oral message on the topic "Stress also has a positive effect on human life"). In this case, the student explains the meaning of the psychological term eustress, rightly believing that this information may not be known to all listeners.

"Somatic feelings are the basis for the General state of feelings. In psychopathies and psychoses (especially in schizophrenia - This is a severe mental disorder leading to emotional disorders, thought process disorders, abnormal behavior), feelings are often subject to changes that make empathy difficult .. "(from an oral message on the topic" Emotions there is a secret power "). This example demonstrates a student's commentary, providing additional information on the topic of the statement, which will help the listener to better understand the situation being described. 
The second group is comments that reveal the process of creating the utterance itself.

"When I was preparing for the report, I found a very interesting video for my topic. And I planned to insert it into my presentation. But for technical reasons I couldn't do it.". During the oral presentation, the student gives a commentary that shows the process of preparing the statement based on the presentation, and, to some extent, reveals the student's intentions and his desire to use the video clip in his presentation.

"PS.: I apologize for the delay in this work. Time, time, time ... Sometimes I feel like I'm becoming a person I write about, heh. The presentation is also coming soon. I tried to leave only the main and interesting points, however, if necessary, I can give additional information. Thank you for your attention! "(From the text of the report on the topic "Abnormal state of feelings"). This example demonstrates the student's comment in the form of a separate paragraph post scriptum, the so-called separative metatext, which conveys several informational messages at once: about the process of creating the initial statement / text, about the reasons for not completing this task on time, about the student's plans regarding the preparation of the presentation for the report.

The third group - comments reflecting the personality of the speaker (student): information about him, his intentions, attitude to his own utterance or the described situation.

"This so-called founder of the method ..." The so-called expression shows the attitude of the speaker (student) to the one about whom he speaks: distrust, disagreement with one or another presented argument.

"One of the public speaking rules is confidence - not to show your emotions ... But how to do it??? How not to show that you are excited... nervous... that it's stress situation for you..." (from the report on the topic "Features of business communication"). This example is interesting in that it combines two types of metatext: verbal and non-verbal, expressed by intonation, raising the voice, gesticulation, and a certain emotional background. It demonstrates, on the one hand, the attitude of the speaker (student) to the content of his own utterance - a kind of disagreement with the apparent simplicity of this rule, and, on the other hand, the personal characteristics of the speaker (student) himself - his emotionality, perhaps the lack of experience in public speaking and, as a result, fear of it.

The experimental study involved 1st and 2nd year foreign language students of the Institute of Education and Practical Psychology, Faculty of Psychology and Pedagogy, Chelyabinsk State University. The results of the pre-experimental stage of the study showed that $62 \%$ of students quite often use various metatextual inclusions in their oral or written statements in a foreign language. $38 \%$ of students use metatextual inclusions in their foreign language oral or written statements quite rarely. According to the test results, the level of foreign language proficiency of students with linguistic reflection is significantly higher than that one of students with insufficiently developed ability for linguistic reflection. The difference rate was $37 \%$.

\section{Conclusion}

Thus, the results of this study showed:

1. The relationship between the ability of students to linguistic reflection and the level of proficiency in the studied foreign language has been established. The reflection of students, realized in speech in the form of metatextual inclusions, is an indicator of a higher level of proficiency in a foreign language in comparison with students who have an insufficiently formed reflection of their foreign language behavior.

2. Students of a foreign language turn to linguistic reflection in the implementation of a foreign language speech activity in the event of certain difficulties. 
3. Linguistic reflection of students is one of the significant indicators of successful mastering of the results of foreign language education, which indicates the need for further study.

\section{References}

1. T.Asten, A. Rynkevich, A. Karpova: ICERI-2020 Proceedings (2020) doi: 10.21125/iceri.2020.0543

2. F.G. Fatkullina, A.K. Suleymanova, L.M. Salimova, V.V. Vorobiev, D.K. Saiakhova, The European Proceedings of Social \& Behavioural Sciences, 228, 1731-1737 (2020). doi: 10.15405 /epsbs.2020.10.05.228

3. E.G. Belyaevskaya, Linguistic personality theory and cognitive linguistics, 34-46. (2017)

4. Yu.N. Karaulov, Russian language and linguistic personality, 167-171 (2010)

5. O.V. Fetor, Vestnik CHelGU, 37(328) (2013)

6. T.B. Mikheeva, Word, Utterance, Text: Cognitive, Pragmatic and Cultural Aspects, 109-114 (2018). Doi: 10.15405/EPSBS.2018.04.02.16

7. M.V. Oborina, Voprosy psiholingvistiki, 3(41) (2019)

8. A.V. Chernov, A.O. Prokhorov, The European Proceedings of Social \& Behavioural Sciences, 76, 665-672 (2017) Doi: 10.15405/epsbs.2017.08.02.76

9. T.P. Ajsuvakova, Reflection as a component of professional self-awareness of a future psychologist, 63 (4) (2019)

10. V.K. Agaragimova, D.M. Daudova, A.K. Mamathanov, Mir nauki, kul'tury, obrazovaniya, 6 (73), 136-137 (2018)

11. T.F. Usheva, T.A. Zhdanko, A.G. Schumovskaya, The European Proceedings of Social \& Behavioural Sciences, 151, $1143-1149$ (2020). doi: 10.15405/epsbs.2020.10.05.151

12. D.I. Gasanova, The European Proceedings of Social \& Behavioural Sciences, 4, 27-34 (2018). doi: 10.15405/epsbs.2018.09.4

13. I.V. Prikhoda, The European Proceedings of Social \& Behavioural Sciences, 38, 254259 (2018). Doi: 10.15405/epsbs.2018.04.02.38

14. I.V. Prikhoda, Filologicheskij aspekt: mezhdunarodnyj nauchnyj i prakticheskij zhurnal, 9(29), 79-83 (2017)

15. S.V. Pervukhina, V.I. Demchenko, E3S Web of Conferences 210, 18033, 1-10 (2020) doi: $10.1051 / \mathrm{e} 3$ sconf/202021018033

16. I.V. Prikhoda, The European Proceedings of Social \& Behavioural Sciences, 38, 327334 (2019) doi: 10.15405/epsbs.2019.08.02.38

17. N. Boeva-Omelechko, M. Zheltukhina, O. Ryabko, G.Matveeva, E. Murugova, I. Zyubina: Space and Culture, India, 6 (4), 112-121 (2018) URL: https://doi.org/10.20896/saci.v6i4.387

18. S.V. Pervukhina, Yazyk I Kultura-Language and Culture. 29, 31-37 (2015) DOI: $10.17223 / 19996195 / 29 / 4$ 